\title{
Formulasi Sediaan Gel Sari Buah Duwet (Syzygium cumini) dengan Basis Karbopol 940 sebagai Gelling Agent
}

Yohanes Juliantoni ${ }^{1^{*}}$, Wahida Hajrin ${ }^{1}$, Windah Anugrah Subaidah ${ }^{1}$

${ }^{1}$ Program Studi Farmasi, Fakultas Kedokteran, Universitas Mataram, Mataram, Indonesia.

DOI : $\underline{\text { https://doi.org/10.29303/sjp.v1i2.14 }}$

\section{Article Info}

Received : 2020-03-13

Revised :-

Accepted: 2020-04-21

\begin{abstract}
Abstrak: Duwet fruit (Syzygium cumini) is a local Indonesian fruit that has many benefits. Duwet juice contains antioxidants that have DPPH free radical activity. But the use of duwet fruit is not practical for modern society. This research was conducted to formulate duwet juice into a gel-based carbopol 940 with the physical quality test of the gel. Duwet fruit extraction was tested for phytochemical screening qualitatively. The gel is made in 5 formulas namely I (100\% aquadest: $0 \%$ ethanol $70 \%)$; II (75\% aquadest: $25 \%$ ethanol $70 \%)$; III (50\% aquadest: $50 \%$ ethanol $70 \%)$; IV (25\% aquadest: $75 \%$ ethanol $70 \%)$; and V ( $0 \%$ aquadest: $100 \%$ ethanol $70 \%$ ). The results showed that Duwet juice contained of flavonoid, polyphenols, and anthocyanins based on phytochemical screening tests. The formula of gel I, II, and III has fulfilled the $\mathrm{pH}$ requirements of 4.5-6.5, homogeneity, and spread capacity of $5-7 \mathrm{~cm}$. Increasing the concentration of $70 \%$ ethanol in the gel formula will increase the $\mathrm{pH}$ value and spread capacity.
\end{abstract}

Keywords: Syzygium cumini, gelling agent, carbopol 940, duwet

Citation: Juliantoni, Y., Hajrin, W., Subaidah, WA. (2020). Formulasi Sediaan Gel Sari Buah Duwet (Syzygium cumini) dengan Basis Karbopol 940 sebagai Gelling Agent. Sasambo Journal of Pharmacy, 1(2), 30-33. doi : https://doi.org/10.29303/sjp.v1i2.14

\section{Introduction}

Senyawa radikal bebas yang bersifat reaktif dapat menyebabkan kerusakan sel kalogen kulit dan matrik dermis sehingga kulit menjadi kering, keriput, bahkan dapat menjadi penuaan dini. Pencegahan dapat dilakukan dengan menggunakan bahan yang memiliki aktivitas antioksidan.

Indonesia merupakan wilayah tropis yang menjadikan kondisinya cocok sebagai tempat tumbuh berbagai macam tanaman. Salah satu tanaman yang perlu dikembangkan dan banyak digunakan adalah buah duwet yang memiliki rasa sepat masam dan berwarna ungu jika telah matang. Jamblang, juwet, jambu keling, jambolan, atau java plum adalah berbagai sebutan untuk buah duwet. Buah duwet mengandung flavonoid yang berperan sebagai antioksidan yang memiliki aktivitas penangkapan radikal DPPH (Juliantoni, 2018).
Flavonoid merupakan salah satu senyawa golongan fenol alam terbesar yang ada pada tumbuhan (Arifin and Ibrahim 2018). Warna ungu dari buah duwet diduga berasal dari kandungan antosianin yang merupakan salah satu sub kelas flavonoid dan dilaporkan menunjukkan kemampuan sebagai senyawa antioksidan (Kim et al., 2009). Selain flavonoid, buah duwet juga mengandung beberapa senyawa golongan polifenol lain seperti tannin (Zhang and Lin 2009).

Teknologi formulasi sediaan farmasi dan sistem penghantaran obat mempunyai peranan penting dalam proses terapi farmasetis. Formulasi gel membutuhkan basis agar menghasilkan gel yang baik. Karbopol 940 merupakan basis gel yang kuat dan aman digunakan secara topikal karena tidak menimbulkan hipersensitivitas pada manusia serta melekat dengan baik (Draganoiu et al., 2009). Karbopol mudah terdispersi dalam air dan dalam konsentrasi kecil dapat 
berfungsi sebagai basis gel dengan kekentalan yang cukup (Rowe et al., 2006). Sediaan gel sari buah duwet akan diuji homogenitas, $\mathrm{pH}$ dan daya sebar. Penelitian ini bertujuan untuk memformulasikan sediaan gel sari buah duwet sebagai antioksidan menggunakan karbopol 940 sebagai gelling agent untuk memperoleh sediaan gel dengan sifat fisik yang memenuhi persyaratan.

\section{Metode Penelitian}

\section{Pengumpulan Sampel}

Buah duwet diambil dari desa sembalun kabupaten Lombok Timur Provinsi Nusa Tenggara Barat. Buah duwet sebelum digunakan terlebih dahulu dibersihkan dari pengotor menggunakan air mengalir. Sari buah duwet diambil dengan cara memisahkan daging buah dan kulit dari bijinya kemudian diblender dan disaring menggunakan kain mori. Ekstrak dikentalkan dengan menggunakan waterbath.

\section{Ekstraksi}

Buah duwet diekstraksi dengan metode perasan menggunakan pelarut aquadest. Sebanyak $3000 \mathrm{~g}$ buah duwet di ekstraksi dengan 3L pelarut aquadest. Ekstrak cair dikentalkan dengan menggunakan tangas air sampai menjadi ekstrak kental.

\section{Uji Kualitatif Senyawa Fitokimia}

\section{Uji Flavonoid}

Ekstrak 0,1 gram dalam cawan ditambahkan 2 $\mathrm{mL}$ etanol kemudian diaduk, ditambahkan serbuk $\mathrm{Mg}$ $0,1 \mathrm{~g}$ dan 3 tetes $\mathrm{HCl}$ pekat. Terbentuknya warna kuning, jingga, merah atau biru menunjukkan adanya senyawa golongan flavonoid (Mojab et al., 2003)

\section{Uji Polifenol}

Ekstrak 0,1 gram dalam cawan ditambahkan dengan $1 \mathrm{~mL}$ larutan $\mathrm{FeCl}_{3} 5 \%$. Jika terbentuk warna biru tua, merah, ungu, biru kehitaman atau hitam kehijauan, menunjukkan adanya senyawa polifenol (Mojab et al., 2003).

\section{Uji Antosianin}

Pengujian adanya senyawa antosianin dapat dilakukan dengan 2 cara. Pengujian pertama dilakukan dengan cara ekstrak sampel sebanyak $50 \mathrm{mg}$ dipanaskan dengan $\mathrm{HCl} 2 \mathrm{M}$ selama 2 menit pada suhu $100{ }^{\circ} \mathrm{C}$, kemudian diamati warna sampel. Apabila warna merah pada sampel tidak berubah, maka menunjukkan adanya antosianin. Pengujian kedua dilakukan dengan ekstrak 50 mg ditambahkan $\mathrm{NaOH} 2 \mathrm{M}$ tetes demi tetes. Hasil positif antosianin ditandai dengan warna merah berubah menjadi hijau biru dan memudar perlahan (Anggriani, 2017).

\section{Formulasi Gel}

Gel dibuat sebanyak 5 formula sesuai dengan formula pada tabel 1 . Selanjutnya gel sari buah duwet diuji sifat fisiknya meliputi homogenitas, $\mathrm{pH}$ dan daya sebar.

Tabel 1. Formula Gel Sari Buah Duwet

\begin{tabular}{lrrrrr}
\hline Formula (gram) & \multicolumn{1}{c}{ I } & \multicolumn{1}{c}{ II } & III & IV & V \\
\hline Karbopol 940 & 1 & 1 & 1 & 1 & 1 \\
TEA & 3 & 3 & 3 & 3 & 3 \\
Gliserin & 10 & 10 & 10 & 10 & 10 \\
Na Benzoat & 0,1 & 0,1 & 0,1 & 0,1 & 0,1 \\
Air & 40 & 30 & 20 & 10 & 0 \\
Etanol 70\% & 0 & 10 & 20 & 30 & 40 \\
Ekstrak & 2 & 2 & 2 & 2 & 2 \\
\hline
\end{tabular}

\section{Uji Sifat Fisik Gel Sari Buah Duwet}

1. Uji $\mathrm{pH}$

Pemeriksaan $\mathrm{pH}$ dilakukan menggunakan $\mathrm{pH}$ meter RoHS PH-009(I).

\section{Uji Homogenitas}

Sediaan gel dioleskan pada permukaan kaca objek, kemudian diamati butiran kasar yang terbentuk atau bagian yang tidak tercampur dengan baik. Jika tidak ditemukan berarti gel homogen.

\section{Uji Daya Sebar}

Sediaan gel ditimbang seberat 0,5 gram, diletakkan ditengah kaca dan ditutup dengan kaca lain yang kemudian diberi pemberat sebesar 50 gram dan 100 gram. Didiamkan selama 1 menit, lalu diukur diameter sebar gel.

\section{Hasil dan Pembahasan}

\section{Pengumpulan Sampel}

Buah Duwet diambil di desa Sembalun Kabupaten Lombok Timur Provinsi Nusa Tenggara Barat.

Pengujian organoleptis pada ekstrak dilakukan dengan cara wadah sampel dibuka dan dibiarkan terkena udara selama 15 menit kemudian data organoleptis dapat ditentukan (Depkes, 2000). Namun data organoleptis hanya merupakan data deskriptis dan bukan parameter penentu standar kemurnian ekstrak bersangkutan (Depkes, 2000).

Tabel 2. Data Organoleptis Ekstrak Buah Duwet

\begin{tabular}{ll}
\hline Organoleptis & Keterangan \\
\hline Rasa & Asam \\
\hline Warna & Ungu \\
\hline Bau & Khas \\
\hline
\end{tabular}




\section{Uji Kualitatif Senyawa Fitokimia}

Hasil uji kualitatif fitokimia sari buah duwet positif mengandung senyawa flavonoid, polifenol, dan antosianin yang dapat dilihat pada tabel 3 .

Tabel 3. Hasil Uji Kualitatif Senyawa Fitokimia

\begin{tabular}{lll}
\hline Uji Kualitatif Fitokimia & Hasil Uji & Kesimpulan \\
\hline Uji flavonoid & Merah & + \\
Uji polifenol & Biru kehitaman & + \\
Uji antosianin & $\begin{array}{l}\text { Merah tidak } \\
\text { berubah }\end{array}$ & + \\
Uji antosianin & $\begin{array}{l}\text { Hijau biru dan } \\
\text { memudar }\end{array}$ & + \\
& perlahan & \\
\hline
\end{tabular}

\section{Uji Sifat Fisik Gel Sari Buah Duwet}

\section{Uji $\mathrm{pH}$}

Nilai pH menunjukkan keasaman suatu bahan, untuk sediaan topikal. $\mathrm{pH}$ sediaan diatur mendekati $\mathrm{pH}$ kulit antara 4,5-6,5 atau idealnya sama, tujuannya untuk menghindari iritasi (Draelos dan Laurend, 2006).

Tabel 4. Hasil Uji $\mathrm{pH}$

\begin{tabular}{lc}
\hline Formula & $\mathrm{pH}$ \\
\hline $\mathrm{I}$ & 5,2 \\
$\mathrm{II}$ & 6,3 \\
$\mathrm{III}$ & 6,5 \\
$\mathrm{IV}$ & 6,6 \\
$\mathrm{~V}$ & 6,6 \\
\hline
\end{tabular}

Terlihat bahwa formula IV dan V kurang ideal namun masih mendekati $\mathrm{pH}$ yang dianjurkan dengan $\mathrm{pH}$ 6,6 yang menyatakan bahwa semakin besar konsentrasi etanol $70 \%$ yang digunakan dalam formula akan meningkatkan $\mathrm{pH}$ dari sedian gel.

\section{Uji Homogenitas}

Hasil pengamatan pada 5 formula tidak ditemukan adanya butiran kasar yang terbentuk atau bagian yang tidak tercampur dengan baik, sehingga 5 formula sediaan gel sari buah duwet homogen.

\section{Uji Daya Sebar}

Pengujian daya sebar termasuk dalam syarat penting dari sediaan gel. Suatu sediaan gel yang memiliki daya sebar yang baik maka zat aktif yang terkandung akan tersebar secara merata dan lebih efektif dalam menghasilkan efek terapi.

Daya sebar semisolid dibagi menjadi 2, yaitu semistiff dan semifluid. Semistiff adalah sediaan semisolid yang memiliki viskositas tinggi sedangkan semifluid adalah sediaan semisolid dengan viskositas rendah. Semistiff memiliki syarat daya sebar $3-5 \mathrm{~cm}^{2}$ dan untuk semifluid adalah 5-7 cm² (Garg et al, 2002). Sdiaan gel bentuk sediaan harus seperti semifluid yang berarti hasil dari uji daya sebar harus memenuhi rentang $5-7 \mathrm{~cm}^{2}$.

Tabel 5. Hasil Uji Daya Sebar

\begin{tabular}{lrrrrr}
\hline Daya Sebar & F I & F II & F III & F IV & F V \\
\hline tanpa pemberat & 5,37 & 5,37 & 5,2 & 5,75 & 6,17 \\
$50 \mathrm{~g}$ & 5,97 & 6,25 & 6 & 6,45 & 6,95 \\
$100 \mathrm{~g}$ & 6,42 & 6,67 & 6,4 & 6,87 & 7,42 \\
Rata-rata & 5,92 & 6,1 & 5,86 & 6,35 & 6,85 \\
\hline Keterangan : & & & & & \\
F = Formula & & & & &
\end{tabular}

Terlihat dari Tabel 5 bahwa nilai rata-rata daya sebar ke 5 formula gel sari buah duwet berkisar antara $5,92 \mathrm{~cm}-6,85 \mathrm{~cm}$, telah memenuhi kriteria yang diberikan. Namun pada formula $V$ dengan pemberat 100 g didapatkan hasil uji daya sebar sebesar $7,42 \mathrm{~cm}$ yang tidak memenuhi syarat. Data juga memperlihatkan adanya peningkatan daya sebar yang sebanding dengan penambahan jumlah etanol $70 \%$ pada formula.

\section{Kesimpulan}

Sari buah duwet (Syzygium cumini) positif mengandung golongan senyawa flavonoid, polifenol, dan antosianin berdasarkan uji skrining fitokimia. Formula sediaan gel sari buah duwet I,II, dan III telah memenuhi persyaratan $\mathrm{pH}$, homogenitas, dan daya sebar. Semakin tinggi konsentrasi etanol $70 \%$ pada formula gel akan meningkatkan nilai $\mathrm{pH}$ dan daya sebar.

\section{Daftar Pustaka}

Arifin, B., Ibrahim, S. (2018). Struktur, Bioaktivitas dan Antioksidan Flavonoid. Jurnal Zarah, 6(1), 21-29. doi: https://doi.org/10.31629/zarah.v6i1

Anggriani, R., Ain, N., Adnan, S. (2017). Identifikasi Fitokimia dan Karakterisasi Antosianin dari Sabut Kelapa Hijau (Cocos nucifera L. var varidis). Jurnal Teknologi Pertanian, 18(3), 163-172. doi: http:/ /dx.doi.org/10.21776/ub.jtp.2017.018.03.16

Depkes. (2000). Parameter Standar Umum Ekstrak Tumbuhan Obat. Jakarta, Indonesia: Departemen Kesehatan Republik Indonesia.

Draelos, Z.D., \& Lauren, A.T. (2006). Cosmetic Formulation of Skin Care Products. New York: Taylor and Francis Group.

Draganoiu, E., A Rajabi, S., S Tiwari. (2009). Handbook of Cosmetic Science and Technology. London: Pharmaceutical Press, 110-113.

Garg, A., Aggarwal, D., Garg, S., Singla, A.K. (2002). Spreading of semisolid formulation: An update. Pharmaceutical Tecnology. 26(9), 84-105. Retreived from 
https://www.researchgate.net/publication/279595 351_Spreading_of_semisolid_formulations_An_upd ate

Juliantoni, Y., Wirasisya, D.G., \& Hasina, R. (2018). Formulasi Nutraseutikal Sediaan Gummy Candies Sari Buah Duwet (Syzygium cumini). Jurnal Kedokteran, 7(2), 9-11. Retrieved from http://jku.unram.ac.id/article/view/177

Kim, D.O., Lee, K. W., Lee, H. J., \& Lee C. Y. (2002). Vitamin $C$ equivalent antioxidant capacity (VCEAC) of phenolic phytochemicals., J Agric Food Chem, 50(13), 3713-7. doi: https://pubs.acs.org/doi/10.1021/jf020071c

Mojab, F., Kamalinejad, M., Ghaderi, N., \& Vahidipour, H. (2003). Phytochemical Screening of Some Species of Iranian Plants, Iranian Journal of Pharmaceutical Research, 2(2), 77-82. Retreived from http://ijpr.sbmu.ac.ir/article_16.html

Robins. (2007). Buku Ajar Patologi. Jakarta, Indonesia: Penerbit Buku Kedokteran EGC.

Rowe, R.C., Sheskey, P.J., Owen, S.C. (2006). Handbook of pharmaceutical excipients (Fifth Edition). Washington DC: Pharmaceutical Press and American Pharmacist Association.

Zhang, L.L., and Lin, Y.M. (2009). Antioxidant tannins from Syzygium cumini fruit, African Journal of Biotechnology, 8(10), 2301-2309. Retreived from https://www.ajol.info/index.php/ajb/article/view $\not 60578$ 